\title{
AC 2007-829: DEVELOPMENT OF AN ONLINE MASTER'S DEGREE IN TECHNOLOGY MANAGEMENT
}

\section{Gregory Arbuckle, Western Kentucky University}

GREGORY ARBUCKLE is currently an Assistant Professor in Technology Management at

Western Kentucky University. He earned his B.S. (Mechanical Technology, 1996) from Indiana

State University, M.S. (Industrial Technology, 1999) from Eastern Illinois University, and Ph.D. (Technology Management, 2004) from Indiana State University. Dr. Arbuckle has over 10 years of experience as a quality control engineer, quality manager, and educator. He is a Certified Industrial Technologist by the National Association for Industrial Technology.

\section{Dale McDaniel, Western Kentucky University}

DALE McDANIEL is currently an Assistant Professor in Architectural and Manufacturing Sciences at Western Kentucky University. He earned a B.S. (Industrial Technology, 1989) from Western Kentucky University, and M.S. (Industrial Technology, 1991) from the University of Central Missouri (formerly Central Missouri State University). He is a Ph.D. candidate in Workforce Education and Development at Southern Illinois University-Carbondale. Mr. McDaniel has over 14 years of experience as an architectural designer, construction manager, trainer, and educator. 


\title{
Development of an Online Master's Degree in Technology Management
}

\begin{abstract}
Continuous advancements in technology have paved the way for growth in distance education (DE). Nearly 90 percent of public institutions for higher education offer some DE courses. As these offerings continue to expand, more institutions are making the move to creating complete online programs, not just courses. This transition is especially viable for graduate education, where many participants are nontraditional students holding full-time employment. Many industrial personnel possess educational backgrounds in technical disciplines, but require management knowledge and skills to advance into management positions. As educational institutions partner with industrial organizations to fulfill this need the preferred delivery method of programs must be examined.

This paper describes a study to determine the need for an online Master of Science in Technology Management in a regional service area. While this program will be available worldwide, our university requires that we demonstrate a regional need for all new programs. Human resource professionals were surveyed to determine their plans for hiring, or placing employees in graduate programs. This study also sought to determine if industrial partners have a preference for the delivery method of master's programs available to their employees.

Survey results indicated that industrial partners were interested in hiring graduates of master's programs in addition to enrolling current employees in these programs. Additionally, industrial partners also showed preferences for online delivery of programs over traditional classroom delivery. As society continues to accept that distance education provides equal quality to that of a traditional delivery, specialized online graduate programs that meet the specific needs of fulltime industrial personnel should also continue to increase.
\end{abstract}

\section{Introduction}

In 1991, Brey predicted that post secondary Distance Education (DE) programs would see an incredible rate of growth through the $1990 \mathrm{~s}^{1}$. At that time less than 100 accredited universities in the United States offered DE courses. By 1998, over 800 institutions were offering DE courses. There is continuous growth in DE courses being offered in the United States today ${ }^{2}$. According to the National Center for Education Statistics (NCES) in the 2000 - 2001 academic calendar year nearly 90 percent of all public 2 and 4-year institutions were offering DE courses ${ }^{3}$. In the development of a new Master of Science in Technology Management degree there are many decisions that must be made about the program. There are several questions about the admission requirements, curriculum, competency testing, and research requirements. Over the last several years however a new issue has arrived for departments developing new programs. How was the program going to be delivered? 


\section{Purpose}

The purpose of this study was to determine if there is a need for an online Master of Science degree in Technology Management in the Western Kentucky University (WKU) service area. While this program will be available worldwide our university requires that we demonstrate a regional need for all new programs. An additional purpose to this study was to determine if our industrial partners have a preference for the delivery method of Master's programs available to them.

\section{Review of Literature}

While distance education is not a new practice in education with correspondence-like courses starting in the late 1800's the large growth of DE courses did not occur until the 1990's '. With the advancement of technology in the United States and rest of the world, online education became a great method for individuals to continue their educational needs. There are several benefits listed for DE courses. Clyburn and Johnson stated "the most frequent response is that DE offers the potential of increased enrollments by giving access to a student population that could not have otherwise attend courses offered by that institution." These types of responses from students are also indicated by Marshall ${ }^{6}$, Burgess and Strong ${ }^{7}$, and Smallwood and Zargari ${ }^{8}$. While all of these authors agree that online learning is a good way to eliminate geographical concerns, they do not all agree on the disadvantages of offering DE courses. The list of disadvantages by the authors listed above includes reducing academic freedom, no "in-person" contact, and not enough time to develop courses. While all of these concerns need to be addressed at each institution the continual growth of DE courses and programs shows that the students are willing to adapt and participate in online programs in order to maintain their current work and family commitments while continuing their education. Magjuka, Shi, and Bonk noted that there are two important factors that have contributed to the increased popularity of online programs 9 . First, online programs offer "any time, any place" access to adult learners who do not want to leave full-time employment and disrupt family life to pursue a degree in a traditional format. Secondly, society has begun to accept distance education as equal in quality to that of face-to-face education.

\section{Methodology}

For this study a list of 230 companies in Western Kentucky University's service area was obtained using the 2005 Kentucky Directory of Business and Industry. This list included the organizations' mailing address and contact information. A survey was sent to Human Resource Managers (HRM) of these organizations asking them to answer questions about hiring and placing current employees into three different graduate programs.

The first section of the survey was designed to determine how many employees the organizations were likely to hire out of three different master's programs. The programs that were listed were a Master of Science in Industrial Technology, Master of Science in Technology Management, and a Master of Business Administration (MBA). The survey asked how likely are you to hire a graduate of each of the following master's programs. The Likert scale ranged from $1-$ not at all 
likely to 5- very likely. The HRMs were then asked to identify how many graduates for these three programs the organizations where likely to hire in the next five years.

The second section of the survey was designed to determine how many employees each organization would like to enroll in a master's program. The same three programs listed above were listed as options. However, this section provides the choice of traditional face-to-face instruction and web-based instruction. The HRMs were asked, how likely are you to place your current employees in each of the following master's programs. The HRMs were asked how many employees they would place into these programs in the next five years.

The last section of the survey was designed to determine if organizations had any policy of promotion with regard to education.

\section{Results}

There were twenty-four useable responses returned to the department for a $10.4 \%$ response rate. The responses were then reviewed for the purpose of this study.

The response for hiring graduates from the three programs was as follows. Eleven out of the 24 $(46 \%)$ organizations stated (ranking of three or higher) that their organization had interest in hiring someone from a Master's of Science in Industrial Technology degree within the next five years. For the Master's of Science Technology Management nine (37.5\%) organizations had a rank of three or higher. Eleven $(46 \%)$ of the organizations indicated that they would be interested in hiring someone with a MBA within the next five years.

The response for delivery of the program face-to-face or online revealed the following data. The average of the twenty-four response for the Master of Science in Industrial Technology was; traditional face-to-face delivery 2 , online delivery 3.15. The average of the twenty-four responses for the Master of Science in Technology Management was; traditional face-to-face delivery 1.84, online delivery 3.15. The average of the twenty-four responses for the MBA was; traditional face-to-face delivery 2 , online delivery 3.31 .

There were several written comments about education and promotion policies within organizations (see Appendix A).

\section{Conclusions}

The results of this survey showed that industrial partners in the WKU service area are interested in hiring graduates of Master's programs and enrolling their employees to these programs. This survey also showed a preference of online delivery of programs over traditional face-to-face programs. As the technology needed for offering DE programs continues to advance, and as wider acceptance of this delivery method continues to grow, higher education institutions are poised to support industry's educational needs. The obstacles that exist as perceived disadvantages to DE programs are not insurmountable; critical thinking, creativity, planning, and training can serve as the catalyst for continued growth and effective education. The authors will 
expand the survey population to determine the need for this program beyond WKU's regional service area.

Upon completion of this study the authors began the development of the curriculum for the online Master's program at Western Kentucky University. A summary of benchmark institutions follows. Of the 15 benchmark institutions, 11 schools offer both the baccalaureate and master's degree in a technical field. The largest program at Central Missouri has 68 faculty members and graduates 235 student each year with a BS degree and 58 students with a master's degree in Technology. The program at Central Missouri is a traditional technology-based program of study and is not offered via the web or internet. The smallest program in technology is offered at Northern Arizona with two faculty members. This program graduates seven baccalaureate students each year and three students with a master's degree in Education. Arizona's degree is offered via the web. Ball State offers a web-based program that is designed for education majors (about six graduates per year), and Indiana State offers a program in Human Resource Development (about 30 graduates per year) that is delivered over the Indiana Telecommunications System. Each of the remaining programs is offered face-to-face and has an emphasis in technology or education.

Western Kentucky University's Master of Science in Technology Management is designed to fulfill the need of individuals seeking to advance their careers into the management of their specific technical areas of expertise, regardless of their educational backgrounds, as long as they are currently working in a technical field. The prospective student must have 4,000 hours of documented industrial work experience and the initiative and drive to complete an online program of study in a 2-year cycle.

Western's proposed program will be delivered entirely on-line, allowing students the flexibility of maintaining their current careers and lives without the need to relocate. Students may complete the program of study in two years by enrolling in two bi-term courses each semester and one course during each summer session. This delivery method corresponds to the recommendations of the adult learning theory which states that adults are more successful in short-term courses as compared to full-term courses. Parsons states "overall the group of students expressed a favorable attitude toward the accelerated nine-week format. ${ }^{10,}$

As a result, a draft program of study was developed and presented to the Architectural and Manufacturing Sciences Department Advisory Board in April 2005. The 21-member board unanimously endorsed the program of study. The Technology Management program requires 27 semester-hours of course work that directly impacts the decision making process for managers in business and industry with responsibility of securing materials, managing processes, assuring quality, implementing methods for continuous improvement while supporting the company's goal of competitiveness. The Master of Science in Technology Management program also requires either a six semester-hour research project or a nine semester-hour research/thesis option. (see Appendix B) 


\section{Recommendation of Further Research}

This master's program has been implemented, and with minimal marketing efforts, currently has enrollment sufficient to support the program. The authors were initially faced with meeting this university's requirement of demonstrating a regional need for such a program prior to developing it. This matter having been accomplished, the authors will expand this study beyond this university's regional service area to include a broader and more diverse population. Online distance education opportunities have no geographic boundaries. Future studies will also include topics of course delivery methods, testing, advising methods, and course discussion methods.

\section{Appendix A}

The following are the responses to the open ended question about the company's policy on promotion and how it relates to education. As can be seen most companies support their employees that want to further education, but few have an established policy of education and promotion.

We do sales and distribution from this office not manufacturing.

In the past, it has been up to the employee to continue their education. We do not have a policy of promotion with regard to education. However, we have a few employees who have chosen to continue their education and would find an on-line program in each of these fields, very beneficial.

We are a small profit recycling business. I have a BS from WKU and the owner has a BA from Vandy. We strongly support education, but few ever have a high school education. (We have 21 full-time employees). But, there is a strong need for higher education in Logan County. I feel that if we had a higher education standard in the community, we would not be facing the problems that we have.

We are a relatively small company with only 2 or 3 management positions. Our education needs are fully filled our printing allowances because we are in a specialty field.

Due to the nature of our business, condition of our equipment, etc.... while we do value education and certainly a Master's degree, we require 2-3 years practical experience, along with a degree to full those positions. Based on our particular market, we do not anticipate much, if any, hiring over the next few years. We have had much difficulty in finding qualified engineering candidates specifically with finding experience in the past.

\section{No Written Policy}

Many of our positions are seniority based. We do hire from external means, most often, for salary positions and do not, nor have we ever had a Masters employee to the best of our knowledge.

No policy in place. 
AFP is a small business with limited advanced positions available. However I feel that higher education brings the opportunity to offer your employer the option to broaden the employee's responsibilities, therefore resulting in higher compensation.

$1^{\text {st }}$ choice is to promote from within. All staff level jobs require a B.S. or B.A. with a graduate degree preferred.

We have no policy on promotion education (BS, MS) preferred.

LVFC reimburse for classes pertaining to business and personal growth. The individuals involved are mostly to be promoted.

Education is paid for all relevant coursework for current or future job progression. Promotions based on qualification and experience. Promotions normally are a factor of increase responsibility and desire to put in longer hours. Education would be a secondary value.

Logan Aluminum supports and encourages employees to gain additional skills and knowledge through education.

We base our promotions and advancement more on performance, however we may increase a Team Member's salary or rate if they complete vital certificates or achievements, ie. QA operator to QA tech, HR specialist to CHRS. We do encourage continuous learning environment and urge all Team Members with Tuition Reimbursements.

Employees an undergraduate or graduate degree is typically promoted before those without degrees; employees with degrees in progress are preferred over others who are not pursuing degrees; Policy states a combination of education and/or experience.

No established policy

\section{Appendix B}

\section{Curriculum:}

AMS 510 Emerging Technologies 3 Hrs - Discovery of powerfully disruptive technologies, evaluating them accurately and implementing change for profitability.

AMS 520 Resource Management 3 Hrs - A comprehensive study of efficient allocation of materials and money. Includes a review of basic decision-making techniques, cost-benefit ratio analysis, depreciation, salvage value of equipment, and time value of money.

AMS 525 Industrial Resource Allocation 3 Hrs - A comprehensive study of efficient allocation of resources. Topics related to manufacturing operation analysis with emphasis on efficient and practical techniques for estimating costs based on existing relationships among inflation, labor, material, forecasting, and the activity. 
AMS 530 Automated Data Collection Systems 3 Hrs - Information systems for industry; collecting and analyzing real time data to make production decisions regarding profitability and quality.

AMS 535 Workforce Development 3 Hrs - Strategies for developing educational opportunities for personnel in industry and appropriate appraisal techniques for program improvement. Includes topics crucial to developing the nation's workforce, including sociological foundations of workforce education, career development theory, needs assessment, developing objectives, performance assessment and private sector providers of workforce education programs.

AMS 590 Operations Leadership 3 Hrs - Provides technical professionals with leadership and management skills needed to be effective throughout their career.

AMS 630 Legal \& Ethical Issues in Technology 3 Hrs - A study of ethics and social responsibility, international and contemporary legal issues in business and industry, and ecommerce.

AMS 650 Industrial Distribution 3 Hrs - An integrated and comprehensive treatment of operations and supply chain issues. Students study how firms link with their supply chain partners to gain a market advantage and competitiveness.

AMS 671 Quality Management 3 Hrs - An examination of philosophies, concepts, tools and techniques used in continuous quality improvement programs.

Non-Thesis Option:

AMS 690 Graduate Project 6 Hrs - An applied research project, using standard procedures of problem identification, possible solutions, and a final report. Can be either field or laboratory based and must be approved by a graduate faculty committee.

Thesis Option:

AMS 571 Research Methods in Technology Management 3 Hrs -A comprehensive study of research methods and experimental design applicable to industrial and technical operations. This course includes a review of basic statistics, quality control techniques, and quality assurance.

AMS 599 Thesis 6 Hrs

\section{Bibliography}

1. Brey, R. (1991). U.S. postsecondary distance learning programs in the 1990s: A decade of growth. Washington D.C.: American Association of Community and Junior Colleges, Instructional Telecommunications Consortium. (ERIC document reproduction service No. ED340418) 
2. Allen, I.E. \& Seaman, J. (2005). Growing by degrees: Online education in the United States, 2005. Needham, MA: Sloan-C. Retrieved Sept 10, 2006, from www.sloanc.org/resources/growing_by_degrees.pdf

3. National Center for Education Statistics, (2003). Fast Facts. Retrieved November 30, 2006 from http://nces.ed.gov/fastfacts/display.asp?id=80

4. Nasseh, B. (1997). A brief history of distance education. Retrieved Feb 23, 2006, from http://www.seniornet.org/edu/art/history.html

5. Clyburn, W.W. \& Johnson, W.C. (2001). A status report on the use of distance education in industrial technology. [Electronic version]. Journal of Industrial Technology, 17(3).

6. Marshall, J.M. (2000). Focus on industry for success. [Electronic version]. Journal of Industrial Technology, 16(3).

7. Burgess, L.A. \& Strong, S.D. (2003). Trends in online education: Case study at Southwest Missouri State University. [Electronic version]. Journal of Industrial Technology, 19(3).

8. Smallwood, J.E. \& Zargari, A. (2000). The development and delivery of a distance learning (DL) course in industrial technology. [Electronic version]. Journal of Industrial Technology, 16(3).

9. Magjuka, R.J., Shi, M. \& Bonk, C.J. (2005). Critical design and administrative issues in online education. Online Journal of Distance Learning Administration, 8(4), Retrieved September 12, 2006 from http://www.westga.edu/ distance /ojdla/winter84/magjuka84.htm.

10. Parsons, G. A., (2005). Non-traditional student perception of barriers to higher education: The effects of an accelerated nine-week term schedule. Dissertation Abstracts International, 66 (06). (UMI No. 3180378) 